\title{
PERANAN ORANG-TUA DALAM MENINGKATKAN KEPATUHAN SISWI MINUM TABLET ZAT BESI FOLAT DI KOTA-DEPOK
}

\author{
The Role of Parents in Improving Compliance of Consuming Iron Folic-Acid Tablet Among \\ High-school Girls Students In Depok City
}

\author{
Apriningsih ${ }^{1}$, Siti Madanijah², Cesilia Meti Dwirianiं ${ }^{3}$, Risatianti Kolopaking \\ 1 Universitas Pembangunan Nasional Veteran Jakarta \\ IInstitut Pertanian Bogor \\ 3 Universitas Islam Negeri Syarif Hidayatulloh Jakarta \\ E-mail: apriningsih@upnvj.ac.id
}

\begin{abstract}
One strategy to reduce anemia in adolescent girl age was through school-based iron folic-acid supplementation. Parents have the important role in improving the female students' compliance. This study aim to identify parent's knowledge, attitude and their role to improve female student's compliance to consume iron folic-acid tablets, mechanism and supplementation period and female student's compliance. Using a cross sectional design, 135 parents had involved for 3 months from 9 high-schools in Depok area.The majority of respondents had less knowledge $(54.1 \%)$ and never received socialization $(61.5 \%)$. T-test and correlation test were applied. There were correlations between parent's knowledge and attitude toward student's compliance $(p=0.00)$. The differences was found in female student's compliance between parents who supervised when drinking at home with those who was not supervised $(p=0,000)$ and between parents who received socialization about anemia and those who never received $(p=0,000)$. The multivariate statistical results showed a fit regression equation about parents' role in improving female student's compliance to consume iron supplement ( $p$ value $=0.000$ ). The regression model shows the greatest influence factor for female sudent's compliance to consume iron folic-acid with supervision at home $(B=0.709, p=0.000$ ), parent's experience got socialization, tablet distribution mechanism and supplemantation schedule of giving iron folic acid $(B=0.551, p=0.01, \beta=0.435, p=0.01$ and $B=0.429, p=0.00$ respectively). It is suggested that school needs to involve parents in the program.
\end{abstract}

Keywords: female students' compliance, consume, iron-folic acid tablet, parents'role

\section{ABSTRAK}

Salah satu program mengatasi anemia remaja putri adalah suplementasi tablet zat besi-folat pada siswi di sekolah. Orang tua berperan meningkatkan kepatuhan siswi minum tablet zat besi-folat. Penelitian ini mengidentifikasi tingkat pengetahuan, sikap dan peran orang-tua dalam meningkatkan kepatuhan siswi, mekanisme dan jadwal suplementasi zat besi-folat serta kepatuhan siswi mengonsumsi tablet zat besifolat yang didapat di sekolah. Desain penelitian adalah cross sectional, melibatkan 135 orang-tua siswi yang diambil secara acak dari sembilan sekolah lanjutan tingkat atas di Kota Depok, selama tiga bulan. Mayoritas responden berpengetahuan kurang $(54,1 \%)$ dan belum pernah mendapatkan sosialisasi tentang tentang anemia remaja putri $(61,5 \%)$. Terdapat korelasi positif antara skor pengetahuan dan sikap orangtua dengan kepatuhan siswi $(p=0,000)$, ada perbedaan kepatuhan siswi minum tablet zat besi-folat antara orang-tua yang mengawasi saat minum di rumah dengan yang tidak mengawasi $(p=0,000)$, dan antara orang-tua yang mendapatkan sosialisasi dengan yang belum mendapatkan sosialisasi $(p=0,000)$. Persamaan regresi yang fit tentang peranan orang-tua dalam meningkatkan kepatuhan siswi minum tablet zat besi-folat di Kota Depok ( $p$ value $=0,000$ ) menunjukkan faktor pengawasan orang-tua yang berpengaruh terbesar $(\beta=0,709, p=0,000)$ selain faktor mendapatkan sosialisasi, mekanisme dan jadwal suplementasi di sekolah $(0,551,0,435$, dan 0,429 masing-masingnya). Sekolah perlu melibatkan orangtua siswi dalam program suplementasi zat besi-folat pada remaja putri.

Kata kunci: Kepatuhan siswi, minum, tablet zat besi-folat, peran orang tua 


\section{PENDAHULUAN}

$\mathrm{M}$ asalah anemia gizi besi masih menjadi masalah gizi mikro di negara berkembang. Anemia gizi besi merupakan penyebab utama Disability Adjusted Life Years (DALY's) pada remaja putri dan menurunkan imunitas, produktivitas, prestasi belajar.1,2World Health Organization (2016) mengestimasikan sebanyak 27 persen remaja putri di negara berkembang menderita anemia. ${ }^{2} \mathrm{Hal}$ ini dapat pula berdampak pada peningkatan angka kematian Ibu dan menurunkan ketahanan anak karena suplementasi zat besi pada masa kehamilan gagal menyimpan cadangan zat besi sesuai kebutuhan. ${ }^{3}$ Prevalensi anemia gizi besi pada remaja putri di Indonesia sebesar 22,7 persen. ${ }^{4}$ Beberapa penelitian menyatakan angka prevalensi anemia remaja putri sekitar 30 persen, bahkan hasil studi di Jawa barat menunjukkan angka prevalensi anemia remaja putri di atas 50 persen. ${ }^{5}$

Pemerintah Indonesia telah mencanangkan program pencegahan dan penanggulangan anemia pada remaja putri dengan memberikan suplementasi zat besi-folat atau yang dikenal dengan tablet tambah darah (TTD) sejak tahun 1997 yang diberikan secara harian saat remaja putri berada dalam periode menstruasi. ${ }^{6}$ Sejak tahun 2016 pemerintah Indonesia menyesuaikan dengan program pemberian TTD yang dicanangkan WHO tahun 2011 yaitu diberikan sepekan sekali berbasis sekolah. Pemberian TTD berbasis sekolah didasarkan pada proporsi remaja putri yang bersekolah sekitar 70 persen. $^{7}$

Beberapa penelitian menunjukkan keunggulan program pemberian TTD secara mingguan dibandingkan harian, diantaranya selain lebih cost effective pemberian TTD mingguan berbasis sekolah pada remaja putri. ${ }^{5}$ Selain itu adanya pengawasan dari pihak sekolah dapat meningkatkan kepatuhan siswi minum TTD. ${ }^{8}$ Selain peran sekolah, peran keluarga terutama orang tua juga merupakan faktor yang penting untuk meningkatkan kepatuhan siswi minum TTD. Teori ekologi sosial menjelaskan bahwa orang tua sebagai orang berpengaruh dalam keluarga berperan dalam memengaruhi perilaku seseorang. ${ }^{9}$ Kerjasama orang tua dan guru untuk memotivasi siswi berperan penting dalam peningkatan kepatuhan siswi minum TTD, 9,10

Penelitian sebelumnya masih sedikit yang mengeksplorasi peranan orang tua dalam keberhasilan program pencegahan dan penanggulangan anemia gizi besi pada remaja putri. Beberapa studi sebelumnya berfokus pada identifikasi pengetahuan, sikap, pola makan dan status anemia besi remaja putri, upaya edukasi gizi pada remaja putri, atau intervensi pemberian pangan sumber zat besi untuk perbaikan status gizi besi remaja putri. ${ }^{10}$, 12,13

Berdasarkan hasil studi awal dari hasil wawancara dengan beberapa guru didapatkan informasi adanya penolakan dari beberapa orang tua terhadap pemberian TTD pada putrinya. Selain itu pihak sekolah memberikan TTD kepada siswi untuk dibawa pulang bila sekolah tidak menyelenggarakan minum TTD bersama di sekolah karena banyak faktor diantaranya masa ujian, libur sekolah dan pada siswi yang tetap menolak minum TTD di sekolah. Penelitian ini bertujuan untuk mengidentifikasi tingkat pengetahuan dan sikap orang tua serta peranannya dalam peningkatan kepatuhan siswi minum TTD agar dapat dilakukan intervensi yang tepat dan efektif.

\section{METODE PENELITIAN}

Penelitian ini merupakan penelitian deskriftif analitik menggunakan rancangan studi potong lintang (cross sectional). Penelitian dilakukan di Kota Depok, Jawa Barat pada November 2018 hingga Februari 2019. Populasi penelitian adalah orang tua siswi sekolah lanjutan tingkat atas (SLTA) yang terdiri atas Sekolah Menengah Atas negeri dan swasta, Sekolah Menengah Kejuruan dan Madrasah Aliyah penerima program suplementasi zat besifolat atau tablet tambah darah (TTD) pada remaja putri di Kota Depok.

Unit sampel penelitian menggunakan unit sekolah yang dipilih menggunakan clustered randomized trial (CRT) teknik secara dua tahap. Pada tahap pertama dilakukan pemilihan puskesmas kecamatan yang memiliki angka remaja berisiko anemia terbanyak berdasarkan data dari hasil penjaringan Kesehatan Dinkes Kota Depok Tahun 2017. Tahap kedua secara acak dipilih delapan sekolah yang menjadi unit 
sampel penelitian. Pada masing-masing sekolah dipilih satu kelas dan berdasarkan jumlah siswi yang ada di kelas tersebut ditentukan jumlah orang tua siswi yang menjadi responden penelitian. Jumlah responden 135 responden yang merupakan ayah, ibu atau wali orang tua siswi penerima Tablet Tambah Darah. Data yang dikumpulkan adalah karakteristik orang tua yang terdiri atas usia, jenis kelamin, tingkat pendidikan terakhir, pekerjaan orang tua saat ini, pendapatan orang tua, pengalaman orang tua melihat media tentang anemia pada remaja putri, pengalaman orang tua mendapatkan sosialisasi tentang anemia, media yang disukai orang tua untuk mendapatkan informasi kesehatan tentang anemia remaja putri, dan perilaku orang tua mengawasi siswi minum TTD bila dibawa ke rumah. Tingkat pengetahuan dan sikap responden tentang anemia dan tablet tambah darah diukur menggunakan kuesioner. Tingkat pengetahuan didapat dari hasil skoring dari pertanyaan tentang definisi anemia, cara mendeteksi anemia, cara pencegahan dan pengobatan anemia,jenis makanan penghambat penyerapan zat besi,manfaat tablet tambah darah, kandungan,cara pemberian dan dosis TTD.Skoring Sikap di dapat dari sikap orang terhadap manfaat dan kemungkinan efek samping pemberian TTD pada remaja putri, persepsi masalah anemia pada remaja putri. Mekanisme dan jadwal pemberian TTD kepada siswi di sekolah juga menjadi variabel independen yang diukur. Kepatuhan siswi minum TTD menjadi variabel dependen yang diukur dengan pola perilaku siswi minum TTD yang mereka terima dari sekolah. Data dikumpulkan dengan wawancara menggunakan kuesioner. Kegiatan cleaning dan pengolahan data dilakukan menggunakan software SPSS 23. Data di analisis secara univariat dengan menampilkan prosentase, nilai rerata (mean), Standard deviasi (SD). Variabel umur dikelompokkan menjadi dua kategori berdasarkan nilai rerata. Analisis bivariat dilakukan dengan uji korelasi dan uji $\mathrm{T}$ untuk melihat apakah ada hubungan dan perbedaan antara variabel independen (karakteristik orang tua, tingkat pengetahuan, sikap dan peranan orang tua serta mekanisme dan jadwal pemberian TTD di sekolah) dengan variabel dependen (kepatuhan siswi minum TTD).
Analisis multivariat dilakukan dengan uji regresi linier untuk melihat faktor yang paling berhubungan dengan kepatuhan siswi minum TTD .

Penelitian ini dilakukan sesuai dengan deklarasi Helsinki dan seluruh prosedur yang melibatkan subyek manusia telah disetujui oleh Komite Etik Universitas Pembangunan Nasional Veteran Jakarta, N0.B/1607/IX/2018/KEPK. Sebelum mengisi kuesioner, responden dijelaskan tentang maksud dan tujuan penelitian, dijelaskan hak dan kewajibannya sebagai responden dan bila bersedia mengisi lembar kesediaan yang disediakan.

\section{HASIL}

Tabel 1 menunjukkan karakteristik sosial ekonomi, akses media dan pengalaman orangtua siswi penerima zat besi-folat atau tablet tambah darah (TTD) di Kota Depok. Lebih dari separuh responden berusia kurang sama dengan 39 tahun $(51,9 \%)$ dan berjenis kelamin perempuan $(85,2 \%)$.Sekitar sepertiga $(38,5 \%)$ orang tua berpendidikan terakhir SLTA, hampir separuh $(48,9 \%)$ ayah bekerja sebagai pegawai, sedangkan lebih dari separuh $(57,8 \%)$ ibu siswi penerima TTD adalah ibu rumah tangga dimana sekitar sepertiganya (38,5\% berpendidikan terakhir SLTA. Tingkat pendapatan keluarga sekitar sepertiga $(30,4 \%)$ keluarga siswi penerima TTD berkisar antara Rp.2.500.000,- hingga Rp.5.000.000,--

Lebih dari separuh orang tua $(55,6 \%)$ belum pernah melihat media tentang anemia pada remaja putri dan hanya sekitar sepertiga $(38,5 \%)$ mengaku pernah mendapatkan sosialisasi edukasi/penyuluhan tentang anemia pada remaja putri maupun program pemberian TTD pada remaja putri di sekolah. Pesan yang sering didapatkan orang tua pada penyuluhan anemia pada remaja putri adalah manfaat TTD $(15,6 \%)$ dan media yang paling sering digunakan yaitu video $(23,0 \%)$. Sekitar separuh $(52,6 \%)$ orang tua bersedia jika diundang ke sekolah untuk menghadiri penyuluhan anemia pada remaja putri, sekitar dua per lima $(40,0 \%)$ orang tua menginginkan waktu penyuluhan pada saat akhir pekan dan lebih dari separuh $(57,0 \%)$ orang tua menginginkan penyuluhan mengunakan media video. 
Tabel 1

Karakteristik Sosial Ekonomi, Akses Media, Pengalaman, Skor Pengetahuan dan Sikap Orangtua Siswi Penerima Tablet Tambah Darah di Kota Depok

\begin{tabular}{|c|c|c|}
\hline Karakteristik Sosial Ekonomi & $\mathrm{n}$ & $\%$ \\
\hline \multicolumn{3}{|l|}{ Usia } \\
\hline - $\quad \geq 39$ tahun & 70 & 51,9 \\
\hline - $\quad<39$ tahun & 65 & 48,1 \\
\hline \multicolumn{3}{|l|}{ Jenis Kelamin } \\
\hline - Laki-laki & 20 & 14.8 \\
\hline - Perempuan & 115 & 85.2 \\
\hline \multicolumn{3}{|l|}{ Tingkat pendidikan ayah } \\
\hline$-<S D$ & 20 & 14,8 \\
\hline - SLTP & 15 & 11,1 \\
\hline - SLTA & 52 & 38,5 \\
\hline$-\quad \mathrm{D} 3$ & 12 & 8,9 \\
\hline - Perguruan Tinggi & 36 & 26,7 \\
\hline \multicolumn{3}{|l|}{ Tingkat pendidikan ibu } \\
\hline$-S D$ & 24 & 17,8 \\
\hline - SLTP & 20 & 14,8 \\
\hline - SLTA & 52 & 38,5 \\
\hline$-\mathrm{D} 3$ & 15 & 11,1 \\
\hline - Perguruan Tinggi & 24 & 17,8 \\
\hline \multicolumn{3}{|l|}{ Pekerjaan ayah saat ini } \\
\hline - Pegawai (PNS atau Swasta) & 66 & 48,9 \\
\hline - Petani & 4 & 3,0 \\
\hline - Wirausaha & 35 & 25,9 \\
\hline - Tidak bekerja & 27 & 20,0 \\
\hline _ Tidak memiliki ayah & 3 & 2,2 \\
\hline \multicolumn{3}{|l|}{ Pekerjaan ibu saat ini } \\
\hline - Pegawai (PNS atau Swasta) & 26 & 19,3 \\
\hline - Wirausaha & 23 & 17,0 \\
\hline - lbu rumah tangga & 83 & 61,5 \\
\hline - Tidak memiliki ibu & 3 & 2,2 \\
\hline Pengalaman melihat media tentang anemia pada remaja putri & 60 & 44,4 \\
\hline \multicolumn{3}{|l|}{ sosialisasi/edukasi tentang anemia remaja putri dan TTD* } \\
\hline - Video & 77 & 57,0 \\
\hline - Leaflet & 21 & 15,6 \\
\hline - Poster & 17 & 12,6 \\
\hline - Lainnya & 17 & 12,6 \\
\hline - Booklet & 4 & 3,0 \\
\hline $\begin{array}{l}\text { Pernah mendapat sosialisasi/penyuluhan/edukasi tentang anemia dan } \\
\text { TTD }\end{array}$ & 52 & 38,5 \\
\hline Melakukan pengawasan pada siswi saat minum TTD di rumah & 57 & 42,2 \\
\hline Skor Pengetahuan orang tua tentang anemia dan suplementasi TTD & $16,76 \pm 4,57$ & $5-2$ \\
\hline Skor Sikap orang tua terhadap program suplementasi TTD rematri & $29,99 \pm 4,44$ & $20-42$ \\
\hline
\end{tabular}


Mayoritas orang tua $(86,7 \%)$ menyatakan putrinya pernah menerima TTD dari sekolah. Pada Tabel 2 terlihat nilai rerata pengetahuan responden tentang anemia dan tablet tambah darah sebesar 16,8 dengan nilai minimum 5,0 dan nilai maksimum 28,0. Sekitar separuh $(54,1 \%)$ responden memiliki pengetahuan yang kurang. Walaupun hampir dua pertiga $(63,7 \%)$ orang tua mengaku mengetahui tentang TTD namun beberapa pengetahuan yang paling tidak/sedikit diketahui orang tua yaitu tentang aturan minum TTD $(93,3 \%)$, kandungan TTD (86,7\%), TTD merupakan suplemen bukan obat $(62,2 \%)$, efek samping TTD $(59,3 \%)$, cara mencegah efek samping TTD $(55,6 \%)$ dan cara mengidentifikasi anemia pada remaja putri $(43,7 \%)$.

Pada Tabel 1 juga terlihat nilai rerata sikap orang tua siswi terhadap program pemberian TTD di sekolah sebesar 29,9 dengan nilai minimum 20,0 dan nilai maksimum 42,0. Lebih dari separuh $(55,6 \%)$ responden memiliki sikap yang baik, sedangkan responden yang memiliki sikap negatif sebesar $44,4 \%$. Sikap negatif terbanyak orang tua terkait anemia dan pemberian TTD pada remaja putri diantaranya adalah minum TTD setelah makan tidak mengurangi rasa mual $(64,4 \%)$, minum TTD menimbulkan efek samping yang berbahaya bagi kesehatan $(48,1 \%)$, tidak yakin remaja putri perlu minum TTD sepekan sekali untuk mencegah anemia $(44,0 \%)$, remaja putri tidak membutuhkan TTD untuk memenuhi kebutuhan gizi $(36 \%)$, putri saya tidak punya masalah kekurangan zat besi $(34,8 \%)$.

Hampir separuh $(45,2 \%)$ responden mengaku putrinya menerima TTD dari sekolah untuk diminum bersama-sama di sekolah. Hampir sepertiga $(29,6 \%)$ responden menyatakan bahwa putrinya menerima TTD dari sekolah untuk diminum di rumah dan hampir seperempat $(23,2 \%)$ responden tidak mengetahui mekanisme pemberian TTD di sekolah. Sekitar separuh $(50,4 \%)$ responden menyatakan putrinya menerima TTD sepekan sekali dari sekolah namun terdapat hampir sepertiga $(32,6 \%)$ responden tidak mengetahui jadwal pemberian TTD pada remaja putri di sekolah (lihat Tabel 2).

Tidak sampai sepertiga $(30,4 \%)$ orang tua menyatakan putri mereka selalu minum TTD di sekolah, hampir seperempat (23\%) orang tua menyatakan bahwa putri mereka tidak meminum TTD secara teratur baik di sekolah maupun di rumah dan orang tua tidak tahu perilaku putrinya dalam mengonsumsi TTD baik di sekolah maupun di rumah $(22,2 \%)$ dan kurang dari seperlima $(16,3 \%)$ orang tua menyatakan putri mereka minum TTD di rumah (lihat Tabel 2).

Tidak sampai separuh $(42,2 \%)$ orang tua menyatakan pernah mengawasi putrinya saat minum TTD di rumah. Lebih dari seperempat $(28,9 \%)$ orang tua tidak mengetahui penyebab siswi tidak minum TTD, namun sekitar seperlima $(20 \%)$ orang tua menyatakan penyebab siswi tidak minum TTD karena lupa, hampir seperlima $(18,5 \%)$ karena absen/tidak masuk sekolah, dan sekitar sepersepuluh $(10,4 \%)$ menyatakan merasa tidak perlu minum. Efek samping yang sering dirasakan siswi setelah minum TTD menurut orang tua yaitu mual $(16,3 \%)$ dan konstipasi $(14,1 \%)$.

Hasil uji korelasi menunjukkan adanya korelasi moderat antara pengetahuan dan sikap orang tua tentang anemia dan pemberian TTD pada remaja putri dengan kepatuhan minum TTD pada siswi di 9 SLTA di Kota Depok ( $r=$ 0,342 dan 0,362 , $p$ value $=0,000$ masingmasingnya). Namun pendidikan ayah, pendidikan ibu dan pendapatan orang tua tidak berkorelasi secara signifikan $(p>0,05)$ (Tabel 3).

Tabel 3 menunjukkan adanya perbedaan kepatuhan siswi minum TTD antara orang tua yang mengawasi dan orang tua yang tidak mengawasi putrinya minum TTD saat di rumah $(P=0,000)$. Begitu pula dengan pengalaman orang tua mendapatkan sosialisasi edukasi tentang anemia, terdapat perbedaan kepatuhan siswi minum TTD antara orang tua yang pernah mendapat sosialisasi tentang anemia dan TTD dengan orang tua yang tidak pernah mendapat sosialisasi anemia dan TTD $(p=0,000)$. 
Tabel 2

Implementasi dan Perilaku Siswi Terkait Program Pemberian Tablet Tambah Darah berdasarkan Informasi dari Orang Tua

\begin{tabular}{|c|c|c|}
\hline Komponen & $\mathrm{n}$ & $\%$ \\
\hline \multicolumn{3}{|l|}{ Implementasi } \\
\hline Remaja putri pernah menerima TTD dari sekolah & 117 & 86,7 \\
\hline \multicolumn{3}{|l|}{ Mekanisme distribusi TTD di sekolah } \\
\hline $\begin{array}{l}\text { - Diberikan kepada siswi untuk diberikan kepada siswi untuk diminum disekolah } \\
\text { bersama-sama }\end{array}$ & 61 & 45,2 \\
\hline - Diberikan kepada siswi untuk diminum di rumah & 40 & 29,6 \\
\hline - Tidak tahu & 34 & 23,2 \\
\hline \multicolumn{3}{|l|}{ Jadwal pembagian TTD di sekolah } \\
\hline - Diberikan sepekan sekali (1 tablet/siswi) & 68 & 50,4 \\
\hline - Satu bulan sekali (4 tablet/siswi) & 5 & 3,7 \\
\hline - Sekali dalam 3 bulan (10-13 tablet/siswi) & 11 & 8,1 \\
\hline - Lainnya & 7 & 5,2 \\
\hline - Tidak Tahu & 44 & 32,6 \\
\hline \multicolumn{3}{|l|}{ Perilaku } \\
\hline - Perilaku siswi minum TTD yang diberikan dari sekolah & 11 & 8,1 \\
\hline - Tidak pernah minum & 31 & 23,0 \\
\hline - Tidak meminum secara teratur baik di sekolah maupun di rumah & 22 & 16,3 \\
\hline - Meminumnya di rumah & 41 & 30,4 \\
\hline - Selalu meminumnya di sekolah & 30 & 22,2 \\
\hline Bila minum di rumah di awasi orang tua & 57 & 42,2 \\
\hline \multicolumn{3}{|l|}{ Waktu minum TTD bila minum di rumah } \\
\hline - Pagi hari setelah sarapan & 20 & 14,8 \\
\hline - Siang hari setelah makan & 5 & 3,7 \\
\hline - Sore hari setelah makan & 6 & 4,4 \\
\hline - Malam hari sebelum tidur & 23 & 17,0 \\
\hline - Tidak tentu waktunya & 81 & 60,0 \\
\hline \multicolumn{3}{|l|}{ Penyebab siswi tidak minum seluruh TTD yang diterima } \\
\hline - Tidak suka rasanya & 11 & 8,1 \\
\hline - Absen/tidak masuk sekolah & 25 & 18,5 \\
\hline - Lupa & 27 & 20,0 \\
\hline - Tidak merasa perlu di minum & 14 & 10,4 \\
\hline - Dilarang ortu/keluarga & 1 & 0,7 \\
\hline - Sakit perut, mual/muntah, sakit kepala & 5 & 3,7 \\
\hline - Tidak tahu & 39 & 28,9 \\
\hline - Siswi pernah merasakan efek samping & 67 & 49,6 \\
\hline \multicolumn{3}{|l|}{ Efek samping yang dirasakan setelah minum TTD } \\
\hline - Mual & 22 & 16,3 \\
\hline - Muntah & 1 & 0,7 \\
\hline - Konstipasi & 19 & 14,1 \\
\hline - Sakit kepala & 7 & 5,2 \\
\hline - Baunya tidak enak & 8 & 5,9 \\
\hline - Lainnya & 8 & 5,9 \\
\hline
\end{tabular}


Tabel 3

Analisis Perbedaan Perilaku Siswi Minum Tablet Tambah Darah menurut Pengalaman Orang Tua Mendapatkan Sosialisasi Program Suplementasi TTD dan Pengawasan Orang Tua

\begin{tabular}{lcccc}
\hline & Mean \pm SD & SE & $p$ & $n$ \\
\hline $\begin{array}{l}\text { Pengalaman orang tua mendapatkan sosialisasi program } \\
\text { suplementasi Tablet Tambah Darah }\end{array}$ & $3,07 \pm 1,12$ & 0,15 & 0,000 & \\
Ya & & & & 57 \\
$\quad$ Tidak & & & & 78 \\
\hline Orang tua mengawasi siswi minum TTD di rumah & $3,45 \pm 1,06$ & 0,19 & 0,000 & \\
$\quad$ Ya & & & & 31 \\
$\quad$ Tidak & & & 104 \\
\hline
\end{tabular}

Tabel 4

Model Persamaan Regresi Berganda Peranan Orang Tua dalam Meningkatkan Kepatuhan Siswi SLTA Minum Tablet Tambah Darah di Kota Depok

\begin{tabular}{lcccc}
\hline Model parameters & $\mathrm{R}$ & $\mathrm{R}^{2}$ & $\mathrm{~B}$ & $\mathrm{p}$ \\
\hline Konstanta & 0,761 & 0,579 & 0,381 & 0,000 \\
Pengawasan orang tua & & & 0,709 & 0,002 \\
Orang tua pernah mendapat sosialisasi tentang anemia & & & \\
dan program pemberian tablet tambah darah pada & & 0,551 & 0,011 \\
remaja putri & & 0,435 & 0,011 \\
Mekanisme distribusi tablet tambah darah di sekolah & & 0,429 & 0,000 \\
Jadwal pemberian tablet tambah darah di sekolah & & &
\end{tabular}

Persamaan regresi berganda

Kepatuhan siswi minum tablet tambah darah $=$

Setelah dilakukan analisis multivariat, variabel independen yang masuk model regresi adalah pengawasan orang tua, pengalaman orang tua mendapatkan sosialisasi/edukasi tentang anemia dan TTD, mekanisme pendistribusian TTD di sekolah dan jadwal pembagian TTD di sekolah. Variabel pengetahuan dan sikap orang tua tentang anemia dan TTD harus dikeluarkan dari model karena tidak signifikan (berturut-turut $p=0,217$ dan $p=0,951$ ). Pada model summary diperoleh koefisien determinasi ( $R$ square) 0,761 , artinya model regresi yang diperoleh dapat menjelaskan 76,1 persen variabel dependen kepatuhan siswi SLTA minum TTD di Kota Depok (lihat Tabel 4). Hasil uji multivariat didapatkan persamaan regresi yang fit tentang peranan orang tua dalam kepatuhan siswi SLTA minum tablet tambah darah di Kota Depok ( $p$
$0,381+0,709$ pengawasan orang tua $+0,551$ orang tua pernah dapat sosialisasi $+0,435$ mekanisme distribusi TTD di sekolah +0,429 jadwal TTD di sekolah

value $=0,000$ ). Persamaan garis menunjukkan variabel yang paling besar pengaruhnya dalam menentukan kepatuhan siswi minum tablet tambah darah adalah variabel adanya pengawasan orang tua di rumah $(ß=0,709)$.

\section{BAHASAN}

Dalam penelitian ini tidak terdapat korelasi signifikan antara pendidikan, pekerjaan dan pendapatan orang tua dengan kepatuhan remaja putri minum TTD. Hal ini dapat disebabkan karena pendidikan, pekerjaan dan pendapatan orang tua belum tentu berkorelasi dengan pengetahuan dan kesadaran orang tua untuk menjadi motivator, pendamping atau pengawas putrinya untuk minum TTD. Dalam 
studi ini mayoritas orang tua berpengetahuan kurang tentang anemia dan tidak mengawasi putrinya untuk minum TTD di rumah. Hasil penelitian Siahaan (2012) yang menyatakan tidak ada hubungan bermakna antara tingkat pendidikan ibu, pekerjaan orang tua dengan status anemia pada remaja putri di Kota Depok. ${ }^{11} \quad$ Namun demikian pendidikan merupakan modal dasar penunjang tingkat sosial ekonomi,sehingga pendidikan orang tua dapat memengaruhi status gizi anak.Retno et al (2017) menyatakan bahwa ayah dan ibu yang berpendidikan rendah berpeluang 2,221 dan 1,945 memiliki remaja anemia dibandingkan ayah dan ibu yang berpendidikan tinggi. ${ }^{12}$ Jenis pekerjaan orang tua berpengaruh terhadap tingkat pendapatan keluarga dan akan memengaruhi kemampuan membeli makanan bergizi untuk anggota keluarganya. ${ }^{13}$ Yamin (2012) mendapatkan adanya hubungan antara pekerjaan ayah dengan kejadian anemia pada remaja putri. ${ }^{14}$

Sebagian besar responden memiliki pengetahuan yang rendah tentang anemia dan program pemberian tablet tambah darah remaja putri. Hal ini dapat dipahami karena memang sebagian besar orang tua mengaku belum pernah mendapatkan sosialisasi dan edukasi tentang anemia dan tablet tambah darah pada remaja putri. Menurut penelitian yang dilakukan oleh Aditianti et al (2015) menyatakan bahwa kepatuhan minum TTD dapat meningkat karena adanya pemberian penyuluhan pada pendamping. ${ }^{15}$ Selain itu program pemberian TTD pada remaja sekolah di Indonesia belum menjadi program yang populer. Rencana Jangka Panjang dan Menengah Nasional (RJPMN) menargetkan 30 persen remaja putri menerima TTD sehingga tidak semua remaja putri menerima tablet tambah darah.

Kurangnya pengetahuan tentang anemia ini menyebabkan sebagian besar orang tua menilai putri mereka tidak memiliki masalah dengan anemia. Hal ini juga diasumsikan menjadi penyebab mereka tidak mengawasi putrinya saat minum TTD di rumah bahkan tidak mengetahui apakah putri mereka patuh minum TTD yang diberikan sekolah atau tidak. Dalam penelitian ini responden yang pernah mendapatkan sosialisasi mengenai anemia pada remaja putri masih rendah. Kurangnya sosialisasi pada orang tua tentang anemia remaja putri dapat mempengaruhi rendahnya kepatuhan minum TTD. Hal ini sejalan dengan penelitian yang dilakukan oleh Aditianti et al (2015) yang menyatakan responden yang memiliki pendamping yang telah diberi penyuluhan lebih patuh mengonsumsi TTD dibandingkan responden yang pendampingnya tidak diberi penyuluhan. ${ }^{15}$ Peningkatan kepatuhan ini disebabkan adanya dukungan dari pendamping berupa mengingatkan untuk minum TTD di malam hari dan memotivasi bila merasa malas dan mual. Sejalan dengan penelitian Zulaekah (2009) yang menyatakan intervensi pendidikan gizi secara komprehensif pada anak, orang tua dan guru berperan terhadap peningkatan kadar hemoglobin anak. ${ }^{17}$

Pengetahuan dan sikap merupakan faktor yang berperan penting dalam terwujudnya perilaku seseorang.Studi ini menemukan adanya korelasi positif antara pengetahuan, sikap orang tua terkait anemia pada remaja putri dan program suplementasi zat besi-folat atau Tablet Tambah Darah. Orang tua yang memiliki pengetahuan dan sikap baik terhadap pentingnya kepatuhan siswi minum TTD akan melakukan pengawasan terhadap siswi ketika minum TTD di rumah. Hal ini sesuai dengan Widjaya et al (2014) yang menyatakan banyak studi merekomendasikan pentingnya edukasi tentang pentingnya pencegahan dan penanggulangan anemia kepada orang tua terutama ibu sebagai bagian dari upaya penanggulangan penurunan angka anemia. Topik edukasinya antara lain tentang masalah anemia pada remaja putri, sumber makanan kaya zat besi, sanitasi, kebersihan diri bersamaan dengan fortifikasi dan suplementasi zat besi. ${ }^{18}$ Selain itu perlu ditambahkan materi pentingnya dukungan motivasi dan pengawasan orang tua kepada siswi dalam mengonsumsi TTD.

Media yang paling disukai sebagian besar responden untuk digunakan dalam sosialisasi berupa video. Video sebagai salah satu jenis multi media memiliki keunggulan dibandingkan media yang lain antara lain video dapat menyajikan materi lebih atraktif secara visual dan audio. ${ }^{19}$ Pemilihan jenis multi media yang tepat dalam memberikan informasi akan merangsang sikap kesehatan yang positif dalam upaya meningkatkan kesehatan. ${ }^{20}$

Program pemberian TTD pada remaja putri sepekan sekali di sekolah seringkali tidak dapat berjalan teratur disebabkan jadwal yang 
berbenturan dengan waktu liburan atau ujian sekolah, sehingga pihak sekolah memberikan TTD ke siswi untuk di minum di rumah. Studi ini juga menemukan bahwa hampir sepertiga $(29,6 \%)$ responden yang menyatakan putrinya menerima TTD dari sekolah untuk di minum di rumah. Dengan demikian peran dukungan orang tua dalam mengawasi siswi minum TTD merupakan hal penting untuk meningkatkan kepatuhan mereka. Hal ini sesuai dengan teori ekologi sosial yang menjelaskan perilaku individu dipengaruhi oleh dukungan dari lingkungan terdekatnya antara lain dari orang tua dan keluarga. ${ }^{21}$ Glick et al (2011) dalam studinya menyatakan kepatuhan dalam pengobatan akan meningkat dengan adanya bantuan dari keluarga dalam mengawasi minum obat $(p<0,001){ }^{22}$ Permatasari et al (2018), Dwiriani et al (2011) dan Kheirouri (2014) juga menyatakan pentingnya dukungan dan motivasi orang tua dalam meningkatkan kepatuhan siswi minum TTD. $6,9,10$

Dukungan dan motivasi orang tua didapatkan dengan terlebih dahulu memberikan sosialisasi dan edukasi kepada orangtua. Kerjasama orang tua dan sekolah dalam memotivasi siswi meningkatkan kepatuhan minum TTD merupakan hal yang sangat penting. Sekolah sebagai perpanjangan tangan sektor kesehatan dalam pendistribusian TTD harus menggandeng orang tua siswi agar kepatuhan siswi meningkat. Hal ini pernah dilakukan di Uttar Pradesh India, dimana sebelum siswa diberikan Tablet tambah darah, orang tua diminta mengisi formulir kesediaan dan diberikan pengarahan oleh kepala sekolah. ${ }^{23}$

Dalam sosialiasi kepada orang tua sebaiknya dijelaskan manfaat minum TTD bagi remaja putri, kandungan zat gizi mikro TTD, aturan minum, kemungkinan efek samping dan cara mencegah terjadinya efek samping, jenis makanan yang dapat menghambat dan membantu penyerapan zat besi serta cara mengidentifikasi remaja yang menderita anemia zat besi.Topik-topik tersebut merupakan topik esensial untuk meyakinkan orang tua akan pentingnya konsumsi TTD pada remaja putri sehingga dapat menjadi motivator bagi siswi untuk mengonsumsi TTD secara teratur. Hasil Riskesdas 2018 menampilkan alasan terbanyak remaja putri kurang patuh mengonsumsi TTD adalah karena merasa tidak perlu minum TTD. ${ }^{4}$
Hal ini menunjukkan kurangnya pengetahuan dan kesadaran akan pentingnya konsumsi TTD untuk mencegah dan menanggulangi anemia pada remaja putri. Penelitian ini menemukan alasan terbanyak siswi tidak patuh dalam mengonsumsi TTD adalah pernah mengalami efek samping $(49,6 \%)$ dan sebagian besar efek samping yang dirasakan adalah rasa mual. Rasa mual dapat terjadi bila TTD diminum dalam keadaan perut kosong dan untuk mencegah rasa mual sebaiknya TTD diminum setelah makan siang atau makan malam sebelum tidur. ${ }^{24}$.Mayoritas orangtua menyatakan remaja putrinya tidak dapat memastikan kalau remaja putrinya minum TTD pada waktu tertentu secara teratur. Hanya $17 \%$ responden menyatakan bahwa remaja putri minum TTD setelah makan malam. Dalam hal ini peran orang tua sebagai pengawasan remaja putri minum TTD perlu di optimalkan.Zulaekah (2009) menyatakan bahwa pemberian edukasi gizi anak kepada orang tua dan guru dapat meningkatkan kadar $\mathrm{Hb}$ anak sekolah selain pemberian tablet tambah darah karena orang tua dapat menjadi pemberi motivasi bagi perubahan perilaku kesehatan anak seperti kebiasaan sarapan, mencuci tangan dan kebiasaan selalu memakai alas kaki. ${ }^{18}$

Mayoritas responden menyatakan tidak mengetahui alasan penyebab putrinya tidak minum TTD, namun sebanyak seperlima (20\%) menyatakan penyebab putrinya tidak minum adalah karena lupa. Faktor lupa merupakan salah satu faktor yang dapat diatasi, yaitu dengan cara sekolah mengadakan minum TTD bersama sepekan sekali dan adanya peran serta orang tua untuk mengingatkan remaja putrinya mengonsumsi TTD sepekan sekali. . Oleh karenanya diperlukan kerjasama antara orang tua dan guru untuk memotivasi remaja putri agar bersedia minum TTD di sekolah sesuai dengan panduan Kemenkes dan Surat Edaran gubernur. ${ }^{24,25}$

Faktor mekanisme dan jadwal pendistribusian tablet tambah darah di sekolah memiliki korelasi positif dengan kepatuhan siswi minum TTD. Mekanisme dan jadwal distribusi TTD yang sesuai dengan pedoman Kemenkes RI tahun 2016 tentang Penanggulangan dan Pencegahan Anemia remaja putri harus diperhatikan. Dalam pedoman tersebut dinyatakan bahwa sekolah mengadakan minum TTD bersama di sekolah sepekan sekali 
merupakan hal yang dapat meningkatkan kepatuhan siswi dan mengurangi faktor lupa. ${ }^{24}$ Namun demikian masih banyak sekolah yang tidak dapat mengadakan minum TTD bersama sepekan sekali disekolah disebabkan banyak faktor. Diantaranya adalah faktor kurangnya kesiapan sekolah menyelenggarakan minum TTD bersama sepekan sekali secara berkesinambungan dan kurangnya pengetahuan, motivasi dan kapasitas sekolah sebagai ujung tombak implementasi program suplementasi zat besi -folat berbasis sekolah.

Penelitian ini memiliki keterbatasan antara lain disebabkan studi ini menggunakan desain studi potong lintang sehingga belum dapat membuktikan hubungan sebab akibat secara lebih akurat, selain itu tidak dilakukan observasi perilaku saat orang tua mengawasi putri-putri mereka minum tablet tambah darah di rumah.

\section{SIMPULAN DAN SARAN}

\section{Simpulan}

Peranan orang tua sangat penting dalam meningkatkan kepatuhan siswi mengonsumsi Tablet Tambah Darah yang dianjurkan WHO dan Kemenkes RI untuk mencegah dan menanggulangi anemia pada remaja putri. Namun hasil penelitian ini menemukan masih kurangnya tingkat pengetahuan dan sikap orang tua tentang anemia pada remaja putri. Hal ini berdampak pada kurang optimalnya peran orang tua dalam meningkatkan kepatuhan siswi mengonsumsi zat besi-folat. Dalam studi ini hanya peranan orang tua dalam memotivasi, mengedukasi dan mengawasi remaja putri dalam mengonsumsi Tablet Tambah Darah masih minim. Padahal suplementasi zat besifolat merupakan program pemerintah untuk menurunkan prevalensi anemia pada remaja putri yang dalam implementasinya memerlukan dukungan semua pihak termasuk keluarga dan masyarakat .

\section{Saran}

Kerjasama orang tua dan sekolah dalam pengawasan kepatuhan siswi minum perlu dibangun dengan meningkatkan pengetahuan, sikap dan peranan orang tua terhadap program pencegahan dan penanggulangan anemia pada remaja putri melalui sosialisasi edukasi maupun penyuluhan kepada orang tua dan guru.Sosialisasi edukasi dapat memanfaatkan media massa ataupun media sosial (Whatsapp, Facebook, line,dll) untuk memudahkan diseminasi informasi dan komunikasi. Penelitian ini dapat dilanjutkan dengan melakukan studi intervensi peningkatan kapasitas orang tua tentang program TTD agar dapat berperan dalam meningkatkan kepatuhan siswi minum TTD dan perbaikan status anemia besi remaja putri.

\section{UCAPAN TERIMA KASIH}

Penulis mengucapkan terimakasih kepada Dinas Kesehatan Kota Depok terutama bagian Gizi dan Kesehatan Keluarga dan Kantor Cabang Dinas Pendidikan Wilayah II yang telah mengizinkan dilaksanakannya penelitian ini, dan juga kepada Kementrian Rriset Teknologi Dikti yang telah memberikan dana penelitian kepada penulis. Terimakasih juga penulis sampaikan kepada petugas yang telah membantu dalam pengumpulan data di lapangan.

\section{RUJUKAN}

1. World Health Organization, Stoltzfus RJ, Dreyfuss ML. Prevention of Iron Deficiency Anaemia in Adolescents Role of Weekly Iron Acid Supplementation. Pediatrics [Internet]. 2013;138(1):46. Available from: http://www.who.int/nutrition/publications/mic ronutrients/guidelines_for_Iron_supplement ation.pdf

2. Melwani V, Dubey M, Khan A, Toppo M, Choudhary $Y$, Priya A. A study to assess the prevalence of anaemia amongst adolescent girls residing in selected slum of Bhopal city. Int J Community Med Public Heal [Internet]. 2018;5(3):1096-9. Available from: http://www.ijcmph.com

3. Deshmukh PR, Garg BS, Bharambe MS. Effectiveness of Weekly Supplementation of Iron to Control Anaemia Among Adolescent Girls of Nashik, Maharashtra, India. J Heal Popul Nutr. 2008;26(1):74-8.

4. Kementerian Kesehatan RI Badan Penelitian dan Pengembangan Kesehatan. Laporan Nasional RISKESDAS 2018. Jakarta; 2019. 
5. Roche M. Adolescent girls' nutrition and prevention of anaemia: a school based multisectoral collaboration in Indonesia. BMC Public Health. 2018;363:k4531:1-6.

6. Permatasari T, Briawan D, Madanijah S. E fektivitas Program Suplementasi Zat Besi pada Remaja Putri di Kota Bogor Effectiveness of Iron Supplementation Programme in Adolescent girl at Bogor City. Media Kesehat Masy Indones. 2018;14(1):1-8.

7. Badan Kependudukan dan Keluarga Berencana Nasional, Badan Pusat Statistik Republik Indonesia. Survei Demografi dan Kesehatan:Kesehatan Remaja 2017. 2017.

8. Muro GS, Gross U, Gross R, Wahyuniar L. Increase in compliance with weekly iron supplementation of adolescent girls by an accompanying communication programme in secondary schools in Dar-es-Salaam, Tanzania. Food Nutr Bull. 1999;

9. Contento IR. Nutrition Education.Linking Research, Theory and Practice. second edi. United State: Jones and Bartlett Publisher;

10. Dwiriani CM, Rimbawan, Hardinsyah, Riyadi $\mathrm{H}$, Martianto D. Pengaruh Pemberian Zat Multi Gizi Mikro dan Pendidikan Gizi terhadap Pengetahuan Gizi, Pemenuhan Zat Gizi dan Status Besi Remaja Putri. J Gizi dan Pangan,. 2011;6(3):171-7.

11. Kheirouri $S$, Alizadeh M. Process evaluation of a national school-based iron supplementation program for adolescent girls in Iran. BMC Public Health. 2014;

12. Tenri $Y$. Hubungan Tingkat Pengetahuan, Asupan Gizi dan Faktor lain Yang Berhubungan Dengan Kejadian Anemia pada Remaja Putri SMA di Kabupaten Kepulauan Selayar Tahun 2012. University of Indonesia; 2012.

13. Briawan D, Sulaeman A, Syamsir E, Herawati D, Center-lppm-ipb S, Masyarakat-fema-ipb DG, et al. Efikasi Fortifikasi Cookies Ubi Jalar untuk Perbaikan Status Anemia Siswi Sekolah Efficacy of Fortified Sweet Potato Cookies for Improving Anemia Status in Female Students. 2013;45(4):206-12.

14. Siahaan NR. Faktor-faktor yang berhubungan dengan status anemia apda remaja putri di wilayah Kota Depok Tahun 2011. Vol. 2011. Universitas Indonesia; 2012.

15. Retno P, Dumilah A, Sumarmi S. Hubungan Kejadian Anemia Dengan Prestasi Belajar Siswi Di SMP Unggulan Bina Insani The Association Between Anaemia Incident and Student Learning Achievement At Bina Insani Junior High School. Amerta Nutr. 2017;331-40.

16. Desita Putri R, Yosephin Simanjuntak B, Gizi J, Kesehatan Kementerian Kesehatan Bengkulu P. Pengetahuan Gizi, Pola Makan, dan Kepatuhan Konsumsi Tablet Tambah Darah dengan Kejadian Anemia Remaja Putri.

17. Aditianti; Yurista,Permanasari; Elisa DJ. Pendampingan minum tablet tambah darah... (Aditianti, dkk). Penelit Gizi dan Makanan. 2015;38(1):71-8.

18. Zulaekah S. Peran Pendidikan Gizi Komprehensif untuk Mengatasi Masalah Anemia di Indonesia. Jurnal Kesehatan. 2009;2(2):169-78.

19. Widjaja IR, Widjaja FF, Santoso LA, Wonggokusuma E. Paediatrica Indonesiana. 2014;54(2):88-93.

20. Al Rajhi AN. Using multimedia presentation in teaching (videos, films) in Oman: A cause study of a primary school. J Teach Educ. 2016;05(01):127-36.

21. Silalahi $V$, Lismidiati $W$, Hakimi $M$, Keperawatan BI, Kedokteran F, Mada UG, et al. Efektivitas Audiovisual dan Booklet sebagai Media Edukasi untuk Meningkatkan Perilaku Skrining IVA Effectiveness of audiovisual and booklet as Education Media to. J Media Kesehat Masy Indones. 2018;14(3):304-15.

22. Glick ID, Stekoll AH, Hays S. The Role of the Family and Improvement in Treatment Maintenance, Adherence, and Outcome for Schizophrenia. 2011;31(1):82-5.

23. Vir SC, Singh N, Nigam AK, Jain R. Weekly iron and folic acid supplementation with counseling reduces anemia in adolescent girls: A large-scale effectiveness study in Uttar Pradesh, India. Food Nutr Bull. 
2008;29(3):186-94.

24. Kementrian kesehatan Republik Indonesia. Pedoman pencegahan dan penanggulanngan anemia pada remaja putri dan WUS. 2016; Jakarta.
25. Gubernur Jawa Barat. Surat Edaran Gubernur Jawa Barat tentang program pemberian Tablet Tambah Darah Remaja putri.pdf. 2018 p. 1. 